\title{
Systematic and zoogeographical characteristics of the oribatid mite fauna (Acari: Oribatida) of Vietnam
}

\author{
Đặc điểm cấu trúc phân loại và địa động vật của khu hệ ve giáp (Acari: \\ Oribatifa) ở Việt Nam
}

Research article

Vu Quang Manh ${ }^{*}$, Dao Duy Trinh ${ }^{2}$, Nguyen Hai Tien ${ }^{3}$, Nguyen Huy Tri ${ }^{1}$, Lai Thu Hien ${ }^{1}$, Ha Tra My', Do Thi Duyen ${ }^{\circ}$

${ }^{1}$ Hanoi National University of Education, 136 Xuan Thuy, Hanoi, Vietnam; ${ }^{2}$ Vietnam National University Hanoi, 144 Xuan Thuy, Hanoi, Vietnam; ${ }^{3}$ Thai Binh University of Medicine and Pharmacy, 373 Ly Bon, Thai Binh, Vietnam; 'Institute of Ecology and Bioresources, Hanoi, Vietnam

\begin{abstract}
The article is a synthesis of the studies on oribatid mites carried out in Vietnam during the period of 1980-2013, and is based on the oribatid materials obtained throughout the country. The oribatid mite fauna (Acari: Oribatida) of Vietnam is diversified, and has high specialization. It is diverse by the number of superfamilies, families, genera and species recorded. However, the number of genera per family, as well as the number of species and subspecies per genus, is not high. $43.75 \%$ and $37.50 \%$ of the total 64 families and subfamilies consist of one and of 2-3 genera, respectively. The only one family Oppiidae Grandjean, 1954 consists of 23 genera. The majority of the genera, $68.10 \%$ of the total, are represented by one species. The only two genera are represented by more than 10 species, namely Galumna Heyden, 1826 and Pergalumna Grandjean, 1936, with 13 and 11 species, respectively. The main zoogeographical characteristics of the oribatid mite fauna of Vietnam are the Oriental species, representing $60.30 \%$ of the total number. It also includes the elements of the Palaearctic - Oriental (12.2\%), the Cosmopolitan (10.6\%), the Afrotropical (Ethiopical) - Oriental $(6.9 \%)$, the Australian - Oriental (5.0\%), the Neotropical - Oriental (3.8\%), the Nearctic - Oriental $(0.9 \%)$, and the Pacific - Oriental $(0.3 \%)$.
\end{abstract}

Để đánh giá cấu trúc phân loại và đặc điểm địa động vật của khu hệ ve giáp Việt Nam (Acari. Oribatida), trên co sở mẫu vật nghiên cưu thu tù toàn lãnh thổ quốc gia, công trình đã tổng hợp và phân tích các kết quả nghiên cúu về ve giáp trong giai đoạn 1980-2013. Khu hệ động vật ve giáp Việt Nam có tính chuyên biệt cao, và rất đa dạng về số luợng họ, giống và loài xác định được. Tuy nhiên số luợng giống trong 1 họ, cũng nhu số lương loài trong 1 giống lại không cao. 43,75\% và $37,50 \%$ của 64 ho và phân ho, tuơng ứng chỉ xác định được có 2 và 3 giống. Duy nhất có ho Oppiidae Grandjean, 1954 ghi nhận được 23 giống. 68,10\% tổng số giống, chỉ xác định được 1 loài. Duy nhất có 2 giống ghi nhận được hơn 10 loài, là Galumna Heyden, 1826 và Pergalumna Grandjean, 1936, tuoong úng có 13 và 11 loài. Đặc điểm địa động vật co bản của khu hệ ve giáp Việt Nam là tính chất Đông phuơng (Oriental), với 60,30\% tổng số loài xác định được. Tính chất địa động vật của nó còn bao gồm các yếu tố sau: Cổ bắc - Đông phưong (Palaearctic-Oriental, 12,2\% tổng số loài xác định được), Toàn cầu (Cosmopolite, 10,6\%), Nhiệt đới Phi châu- Đông phuong (Afrotropical (Ethiopical)-Oriental, 6,9\%), Úc châu - Đông phuơng (Australian-Oriental, 5,0\%), Tân nhiệt đói - Đông phương (Neotropical-Oriental, 3.8\%), Vùng cưcc - Đông phưong (Nearctic-Oriental, 0.9\%), và Thái Bình Dưong - Đông phưong (Pacific-Oriental, 0,3\%).

Keywords: $\quad$ oribatida, systematic, zoogeography, Vietnam 


\section{INTRODUCTION}

Oribatid mites (Acarina: Oribatida) are small arachnids (Microarthropoda), comprising the main component of microarthropod populations in the soil ecosystem, and are an important component in all biological processes taking place in soil. They disperse bacteria and fungi, both externally on their body surface, or by feeding, with subsequent survival of spores during passage through their alimentary tracts. Others are intermediate hosts for important tapeworm parasites (Cestoda) of animals (Ghilarov \& Krivolutsky 1975, Behan-Pelletier 1999) [4, 13].

The study on oribatid mites of Vietnam started in 1967 by Hungarian oribatologists (Balogh \& Mahunka 1967) [3]. It continued in the 1980's, and has obtained the important results (Golosova 1983 \& 1984, Vu Quang Manh 1985, Jeleva \& Vu 1987, Mahunka 1987, 1988 \& 1989) [14, 16, $17,18,28]$. However, because of the diverse fauna of the tropical soil ecosystem of Vietnam the studies on oribatid mites of Vietnam are still not enough sufficient (Krivolutsky et al. 1997, Vu \& Nguyen 2000, Vu Quang Manh 2007, 2012 \& 2015, Dao Duy Trinh et al. 2010, Vu et al. 2010, Ermilov et al. 2011, Ermilov \& Vu 2012, Nguyen Hai Tien \& Vu Quang Manh 2012, Nguyen Huy Tri et al. 2014, Fernandez et al. 2014 \& 2015) [5, 9, 11, 12, 15, 20, 30, 31, $32,34,35,36]$.

In recent years, the Russian colleague Sergey G. Ermilov and his collaborators have made a significant contributions to the knowledge of the oribatid mite fauna of Southeast and Southwest of Vietnam. However, many of their oribatid specimens have been obtained by unofficial lines, and Ermilov rarely collected materials by himself in the field. Their data on the geographical locations and natural conditions of Vietnam are founded on incorrect and sometime on illegal sources. In particular, the administrative maps of the socialist republic of Vietnam in their publications are introduced fully false, lacking islands and the island regions of the Vietnam (Ermilov et al. 2012, Ermilov \& Anichkin 2014, Ermilov 2015, Minor \& Ermilov 2015) [7, 8, 10, 19]. Therefore, the data on Vietnam's oribatid mites given by the Russian colleague Sergey G. Ermilov and his coauthors must be checked and revised carefully, before consulting them. Even so, although lacking of knowledge and right source of Vietnam's nature, this is an encouraging attempt by Russian colleague on study of oribatid mites of Vietnam, and it showed up the importance of the soil oribatid mites of Vietnam.

This article is a synthesis of the studies on oribatid mites carried out in Vietnam during the period of 1980-2013, and is based on the oribatid materials obtained throughout the country. Its aim is to characterize the systematic and zoogeographical characteristics of the oribatid mite fauna of Vietnam.

\section{MATERIALS AND METHODS}

\subsection{Study area}

During the period of 1980-2013, oribatid specimens obtained throughout Vietnam, including fifty sites located in
27 provinces, and from all of the 8 natural geographical regions of Vietnam, namely Northwest, Northeast, Red River Delta, North Central Coast, South Central Coast, Central Highlands, Southeast, and Mekong River Delta (Vu, Taillard 1994) [37]. Fifty study sites were classified into six main types, as follows: Natural forest, Human-disturbed forest, Grassland and scrub, Grassland, Cultivated land with perennial and annual plants, and Agricultural land with annual plants (Vietnam Ministry of Agriculture and Rural Development 2006) [26]. The study soils were arranged in a six main groups: Coastal saline-acid soil, Acid alluvial soil, Neutral alluvial soil, Ferralitic reddish brown soil, Ferralitic brownish soil derived from limestone, Reddish brown soils derived from basic and intermediate magmatic rocks (Vietnam National Institute for Soils and Fertilizers 2002) [27].

\subsection{Sampling and extraction}

Soil samples were taken according to soil vertical layers, as follows: Forest litter, and soil vertical layers of $0-10 \mathrm{~cm}$, $10-20 \mathrm{~cm}, 20-30 \mathrm{~cm}$. Soil samples were taken by rectangular metal sampler, with $\left(0,25 \mathrm{~m}^{2}\right)$ surface area, $20 \mathrm{~cm}$ in depth and with both ends open. Forest litter samples were taken from the total forest litter covered an area of $\left(0,25 \mathrm{~m}^{2}\right)$. Modifications of Berlese-Tullgren funnels were used for extraction of oribatid mites from the obtained materials. An extraction lasted seven days in the laboratory at normal air condition of $25-30^{\circ} \mathrm{C}$. Extracted oribatid mites were preserved in $70^{\circ}$ ethanol, sorted and counted (Edwards 1991) [6].

\subsection{Identification and data analysis}

Oribatida materials are identified mainly after Balogh (1992), Gilyarov \& Krivolutsky (1975), Balogh \& Balogh (1988, 1989, 2002), Norton \& Behan-Pelletier (2009), Schatz et al. (2011), and Subias (2013) [1, 2, 13, 22, 23, 24]. A zoogeographical characteristic of the oribatid mite fauna of Vietnam is analyzed according to the World zoogeographical regions, consisting NE. Nearctic, PA. Palaearctic, NO. Neotropical, AF. Afrotropical (Ethiopian), OR. Oriental, AU. Australian, PC. Pacific, and AN (Illies 1974, Udvardy 1975) [25].

\section{RESULT AND DISCUSSION}

\subsection{Species biodiversity}

Table 1 presents the species diversity and an analysis of a systematic characteristics of the oribatid mite fauna of $\mathrm{Vi}$ etnam, consulting to classifications of Gilyarov \& Krivolutsky (1975), Balogh \& Balogh (2002), Norton \& Behan-Pelletier (2009), Schatz et al. (2011), and Subias (2013) $[2,13,22,23,24]$. In the table introduced are also a number of superfamilies per order, of families per superfamily, of genera per family, as well as a number of species per genus. 
Table 1. Systematic characteristics of the oribatid mite fauna of Vietnam

\begin{tabular}{lll} 
No & Infraorder & Superfamily \\
\hline I & ENARTHRONO & 1.HYPOCHTHONOID \\
& TA Grandjean, & EA Berlese, 1910 \\
& & \\
& & \\
& & 2. \\
& & PROTHOPLOPHORI \\
& & \\
& & \\
& & \\
& & \\
& & \\
II & MIXA ENing, 1917 \\
& Grandjean, 1969 & PHTHIRACAROIDEA \\
& & Perty, 1841
\end{tabular}

$$
4 .
$$

EUPHTHIRACAROID

EA Jacot, 1930

5. LOHMANNIOIDEA Berlese 1916

6. CROTONIOIDEA Thorell, 1876
2. Cosmochthoniidae Grandjean, 1947 niidae Grandjean, 1947

4.Prothoplophoridae Ewing, 1917

5. Steganacaridae Niedbala, 1986

.

6. Phthiracaridae Perty, 1841

7. Oribotritiidae

Grandjean, 1954

8. Euphthiracaridae Jacot, 1930

9. Lohmanniidae Berlese, 1916
3. Sphaerochtho-

\section{Genus}

Species

\& Subspecies

1
1913

2. Eohypochthonius Jacot, 1938

3.Eniochthonius Grandjean, 1933

4. Cosmochthonius Berlese, 1910

5. Sphaerochthonius Berlese, 1910

6. Apoplophora Aoki, 1980

7.Arthrhoplophora Berlese, 1910

8. Arphthiracarus Niedbala, 1994

9. Atropacarus Ewing, 1917

10. Austrophthiracarus Balogh et Mahunka, 1978

11. Plonaphacarus Niedbala, 1986

12. Hoplophorella Berlese, 1923

13. Phthiracarus Perty, 1841

14. Indotritia Jacot, 1929

15. Oribotritia Jacot, 1924

16. Sabahtritia Mahunka, 1987

17. Rhysotritia Markel \& Meyer, 1959

18. Haplacarus Wallwork, 1962

19. Javacarus Balogh, 1961

20. Lohmannia Michael, 1898

21.

Grandjean, 1934

Meristacarus

22. Mixacarus Balogh, 1958

23. Papilacarus Kunst, 1959

24. Vepracarus Aoki, 1965

10. Malaconothridae Berlese, 1916

25. Trimalaconothrus Berlese, 1916

11. Nothridae Berlese, 1896

\section{Nothrus Koch, 1836}

27. Afronothrus Wallwork, 1961

28. Allonothrus Hammer, 1953

29. Grandjean, 1931
12. Trhypochthoniidae Willmann, 1931 Archegozetes 


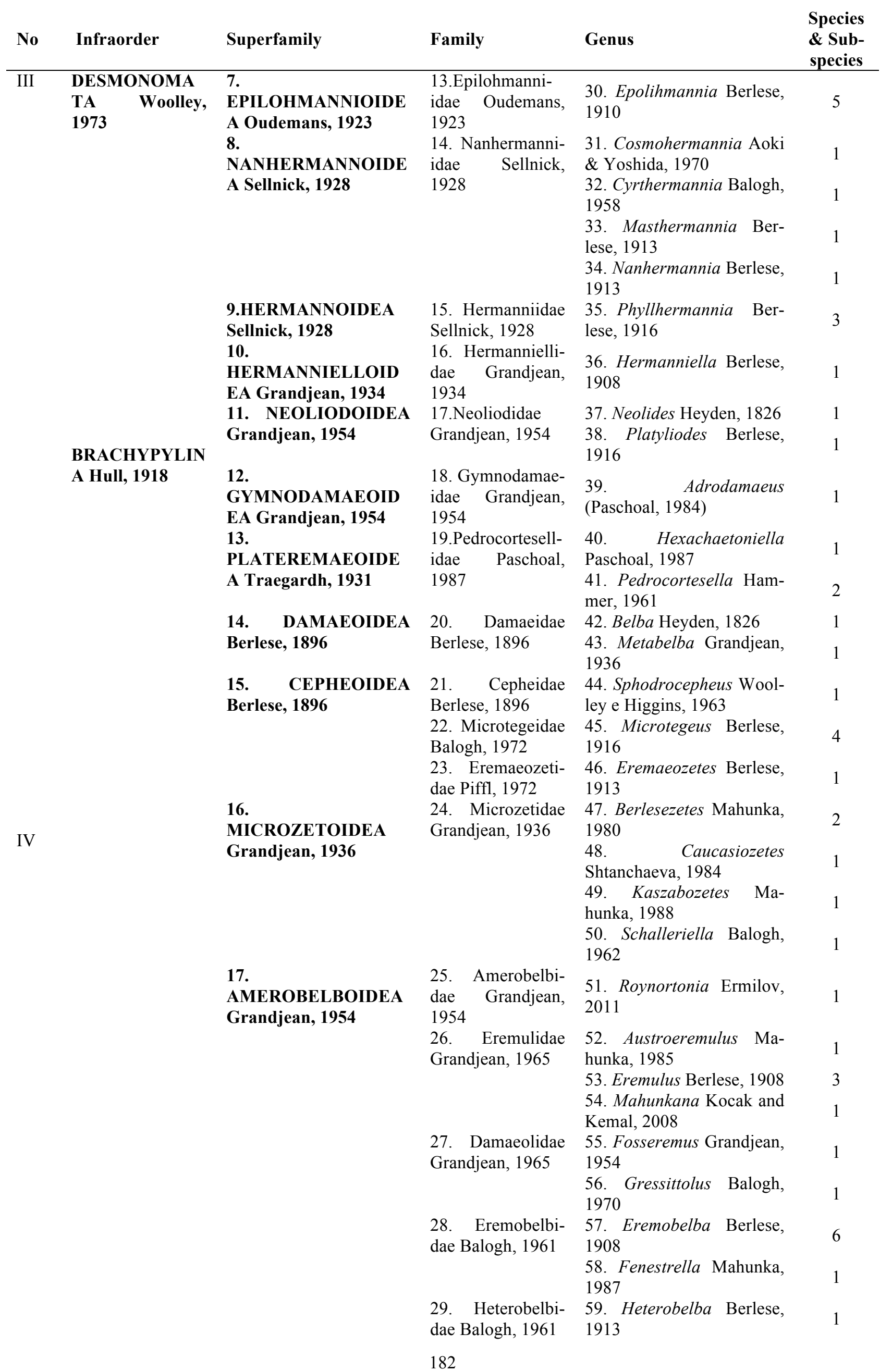




\begin{tabular}{ll} 
No Infraorder & Superfamily \\
\hline & \\
& 18. \\
& ZETORCHESTOIDEA \\
& Balogh, 1961 \\
& 19. GUSTAVIOIDEA \\
& Oudemans, 1900
\end{tabular}

Family

Genus

Species

Balogh , 1961

60. Basilobelba Balogh,

31.Zetorchestidae

Michael, 1898

\& Subspecies

32. Astegistidae Balogh, 1961

33. Peloppiidae

Balogh, 1943

20. CARABODOIDEA 34. Carabodidae

C. L. Koch, 1837

C.L.Koch, 1837 Aoki, 1959

21.

TECTOCEPHEOIDE A Grandjean, 1954

22. OPPIOIDEA Grandjean, 1954

Balogh, 1961
35. Nipobodidae
36.Tectocephei-
dae Grandjean,
1954

37. Otocepheidae Balogh, 1961
71. Leobodes Aoki, 1965

72.Tectocepheus Berlese, 1896

73.Tegeozetes Berlese, 1913

74.Otocepheus (Acrotocepheus) Aoki, 1965

75.Archegotocepheus (Megalotocepheus) Ma- 1 hunka, 1988

76.Dolicheremaeus Jacot, 8 1938

77.Eurostocepheus Aoki, 1 1965

78. Eremella Berlese, 1913

39.Granuloppiidae Balogh, 1983

79. Gigantoppia Mahunka, 2008

80. Granuloppia Balogh, 1958

40. Oppiidae Grandjean, 1954

81. Acroppia Balogh, $1883 \quad 1$
1958

61. Zetorchestes Berlese, 1888

62. Cultroribula Berlese, 1908

63. Ceratoppia Berlese,

1908

64. Furcoppia Balogh et Mahunka, 1969

65. Aokiella Balogh et Ma-

hunka, 1967

66. Austrocarabodes Ham-

mer, 1966

67. Chistyakovella Ermi-

lov, Aoki, Anichkin, 2013

68. Gibbicepheus Balogh, 1958

69. Pentabodes P.Balogh, 1984

70. Carabodes (Phyllocarabodes) Balogh et Mahunka, 1969

1 2

2

1

2

2

3

1

82. Arcoppia Hammer, 6 1977

83. Belloppia Hammer, 1 1968

84. Brachioppiella Hammer, 1962

85. Congoppia Balogh, 1 1963

86. Cryptoppia Csiszár, 1 1961

87. Hammerella Ermilov, Shtanchaeva, Subias, Anichkin, 2012

88. Helioppia Balogh, 1983 


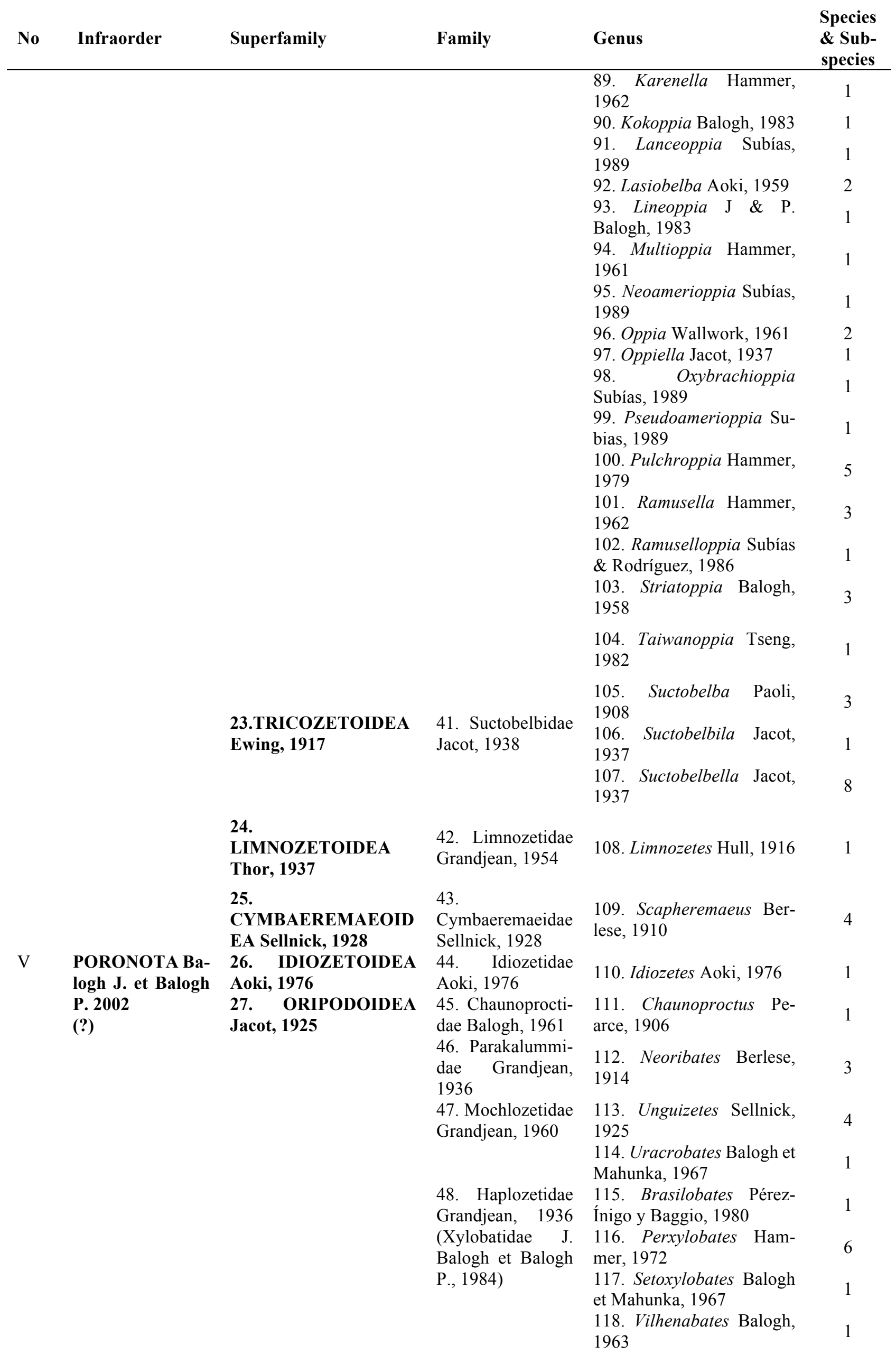




\begin{tabular}{lll} 
No Infraorder & Superfamily & Family \\
\hline
\end{tabular}

49. Protoribatidae Balogh Balogh J. Balogh et P. Balogh, 1984

(1) Protoribatinae Balogh Balogh J. Balogh et P. Balogh, 1984 (Subfamily)

(2) Liebstadiinae Balogh Balogh J. Balogh et P. Balogh, 1984 (Subfamily)

50. Oribatulidae Thor, 1929

51. Haplozetidae Grandjean, 1936

52. Scheloribatidae 1953

\section{Genus}

119. Xylobates Jacot, 1925

Species

\& Subspecies

120. Protoribates Berlese, 3 1908

121. Liebstadia Oudemans, 1906

122. Cordiozetes Mahunka, 1983

123. Oribatula Berlese,

1896

124. Sellnickia Oudemans, 1927

125. Zygoribatula Berlese, 1916

126. Cosmobates Balogh, 1959

127. Indoribates Willmann,

1935

128. Magnobates Hammer, 1967

129. Peloribates Berlese, 1908

130. Rostrozetes (Trachyoribates) Sellnick, 1925

6

131. Euscheloribates

Kunst, 1958

132. Fijibates Hammer, 1971

133. Ischeloribates Corpuz-Raros, 1980

134. Nanobates Balogh et Mahunka, 1980

135. Philoribates L.A.Corpuz-Raros, 1980

136. Rhabdoribates Aoki, 1967

137. Scheloribates Berlese, 1908

138. Tuberemaeus Sellnick, 1930

53. Oripodidae Jacot, 1925

139. Cosmopirnodus Balogh, 1970

140. Oripoda Bank, 1904

141. Subpirnodus Mahunka, 1988

142. Truncopes Grandjean, 1956

54. Birobatidae J. Balogh et P. Balogh, 1984

143. Brachyoripoda Balogh, 1970

55. Mycobatidae Grandjean, 1954

144 1913
1

2

1

7

5

1

1

1

1

1

1

8

2

1

1

1 


\begin{tabular}{|c|c|c|c|c|c|}
\hline No & Infraorder & Superfamily & Family & Genus & $\begin{array}{l}\text { Species } \\
\text { \& Sub- } \\
\text { species }\end{array}$ \\
\hline & & $\begin{array}{l}28 . \\
\text { CERATOZETOIDEA }\end{array}$ & $\begin{array}{l}\text { 56. Ceratozetidae } \\
\text { Jacot, } 1925\end{array}$ & $\begin{array}{l}\text { 145. Ceratozetes Berlese, } \\
1908\end{array}$ & 2 \\
\hline & & Jacot, 1925 & & $\begin{array}{l}\text { 146. Fuscozetes Sellnick, } \\
1928\end{array}$ & 1 \\
\hline & & & $\begin{array}{l}\text { 57. Austrachipte- } \\
\text { riidae Luxton, }\end{array}$ & $\begin{array}{l}\text { 147. Austrachipteria Ba- } \\
\text { logh et Mahunka, } 1966\end{array}$ & 1 \\
\hline & & & 1985 & $\begin{array}{l}\text { 148. Lamellobates Ham- } \\
\text { mer, } 1958\end{array}$ & 4 \\
\hline & & & & 149. Paralamellobates & \\
\hline & & & & $\begin{array}{l}\text { Bhaduri y Raychaudhuri, } \\
1968\end{array}$ & 3 \\
\hline & & & $\begin{array}{l}58 . \quad \text { Punctori- } \\
\text { batidae }\end{array}$ & $\begin{array}{l}\text { 150. Punctoribates Subías, } \\
\text { Kahwash y Ruiz, } 1990\end{array}$ & 1 \\
\hline & & $\begin{array}{l}29 . \\
\text { ORIBATELLOIDEA }\end{array}$ & $\begin{array}{l}\text { 59. Oribatellidae } \\
\text { Jacot, } 1925\end{array}$ & $\begin{array}{l}\text { 151. Novoribatella Engel- } \\
\text { brecht, } 1986\end{array}$ & 1 \\
\hline & & Jacot, 1925 & & $\begin{array}{l}\text { 152. Oribatella Banks, } \\
1895\end{array}$ & 3 \\
\hline & & & $\begin{array}{l}\text { 60. Achipteridae } \\
\text { Thor, } 1929\end{array}$ & $\begin{array}{l}\text { 153. Achipteria Berlese, } \\
1885\end{array}$ & 1 \\
\hline & & & & $\begin{array}{l}\text { 154. Parachipteria Ham- } \\
\text { men, } 1952\end{array}$ & 1 \\
\hline & & $\begin{array}{l}\text { 30. GALUMNOIDEA } \\
\text { Jacot, } 1925\end{array}$ & $\begin{array}{l}\text { 61. Galumnellidae } \\
\text { Piffl, } 1970\end{array}$ & $\begin{array}{l}\text { 155. Galumnella Berlese, } \\
1917\end{array}$ & 2 \\
\hline & & & $\begin{array}{l}\text { 62. Galumnidae } \\
\text { Jacot, } 1925\end{array}$ & $\begin{array}{l}\text { 156. Allogalumna Grand- } \\
\text { jean, } 1936\end{array}$ & 1 \\
\hline & & & & $\begin{array}{l}\text { 157. Dimidiogalumna En- } \\
\text { gelbrecht, } 1972\end{array}$ & 1 \\
\hline & & & & $\begin{array}{l}\text { 158. Galumna Heyden, } \\
1826\end{array}$ & 13 \\
\hline & & & & $\begin{array}{l}\text { 159. Globogalumna P. y G. } \\
\text { Palogh, } 1990\end{array}$ & 1 \\
\hline & & & & $\begin{array}{l}\text { 160. Leptogalumna Ba- } \\
\operatorname{logh}, 1960\end{array}$ & 1 \\
\hline & & & & $\begin{array}{l}\text { 161. Neogalumna Hammer, } \\
1973\end{array}$ & 1 \\
\hline & & & & $\begin{array}{l}\text { 162. Pergalumna } \\
\text { Grandjean, } 1936\end{array}$ & 11 \\
\hline & & & & $\begin{array}{l}\text { 163. Trichogalumna } \\
\text { Balogh, } 1960\end{array}$ & 3 \\
\hline $\begin{array}{l}\text { To- } \\
\text { tal }\end{array}$ & 5 infraorders & 30 superfamilies & $\begin{array}{l}62 \text { families } \\
\text { ( } 2 \text { subfamilies) }\end{array}$ & 163 genera & $\begin{array}{c}320 \\
\text { species, } \\
\text { subspec } \\
\text { ies }\end{array}$ \\
\hline
\end{tabular}

Up to 2014, the oribatid mite fauna of Vietnam is represented by 320 species (including 4 subspecies), belonging to 163 genera, 62 families (not including two subfamilies), and 30 superfamilies (Balogh, Balogh 2002, Norton, Behan-Pelletier 2009, Schatz et al. 2011, and Subias 2013). Among the three hundred and twenty species (320 species, $100 \%$ ) recorded from Vietnam, one hundred and twenty species (120 species, $37.50 \%$ of the total number), were described new for science. One hundred and eleven species (111 species, $34.68 \%$ of the total number), have been found only in Vietnam, and are probably endemic species. One hundred and fifty five (155) species, representing $48.44 \%$ of the total oribatid fauna, were new record for Vietnam (Table 1). After Subias (2013) [24], the World oribatid fauna comprised 10,342 species and subspecies, belonging to 1,249 genera and 163 families. In comparison with the World oribatid mite fauna the one of Vietnam occupies
$3.09 \%$ (320 vs. 10,342 species), $13.05 \%$ (163 vs. 1,249 genera), and $38.03 \%$ (62 vs. 163 families) of the World fauna (Vu Quang Manh 2013, 2015 [33, 34].

In general, the oribatid mite fauna of Vietnam is very diverse, with a high number of species probably endemic. However, these data still not completely.

\subsection{Systematic characteristics}

Table 2 presents the oribatid systematic structure according to the number of genera per family. Almost all of the families consist of $1-3$ genera, $43.75 \%$ and $37.50 \%$, respectively, of the total 64 families and subfamilies. The families consisting of 4-5, and of 6-10 species are few, only $10.94 \%$ and $6.25 \%$, respectively. Only one family consists of more 
than 10 species, the family Oppiidae Grandjean, 1954 con-

sisting of 23 genera (Table 1 and 2).

Table 2. Systematic characteristics of the oribatid mite fauna according to the number of genera per family

\begin{tabular}{llllll}
\multicolumn{1}{rl}{ Number of genera per family } & $\mathbf{1}$ & $\mathbf{2 - 3}$ & $\mathbf{4 - 5}$ & $\mathbf{6 - 1 0}$ & $\mathbf{> 1 0}$ \\
Total & & & & & \\
\hline $\mathbf{6 4}$ families and subfamilies & 28 & 24 & 7 & 4 & 1 \\
$\mathbf{1 0 0} \%$ & 43.75 & 37.50 & 10.94 & 6.25 & 1.56
\end{tabular}

Table 3 presents systematic characteristics of the oribatid mite fauna according to the number of species per genus. Almost all of the genera consist of one species, $68.10 \%$ of the 163 genera. The genera comprising of 2-3, 4-5 and 6-
10 species are few, only $18.41 \%, 6.13 \%$ and $6.13 \%$, respectively, of the total of 163 genera. Only two genera comprise of more than 10 species, namely Galumna Heyden, 1826 and Pergalumna Grandjean, 1936, with 13 and 11 species, respectively (Table 1 and 3 ).

Table 3. Systematic characteristics of the oribatid mite fauna according to the number of species per genus

$$
\begin{array}{llllll}
\text { Number of species per genus } & 1 & 2-3 & 4-5 & 6-10 & >10
\end{array}
$$

Total

$$
100 \%
$$$$
163 \text { genera }
$$

In general, according to the number of superfamilies, of families, of genera, as well as of species and subspecies recorded, the systematic characteristics of the oribatid mite fauna of Vietnam is diversified. However, the number of genera per family, as well as the number of species per genus are not high.

\subsection{Zoogeographical characteristics}

Table 2 presents the oribatid systematic structure according to the number of genera Vietnam is completely distributed in the in the Southeast Asia. Hammer and Wallwork (1979) considered that the source for the oribatid mite fauna of the south Pacific is probably Southeast Asia and that dispersal has occurred over seas, via island "stepping stones". However, Vietnam is a highly interesting region from a zoogeographical aspect. Although the whole country is mainly in the Oriental region, there is distinct differentiation between northern and southern parts of the country, and even between different subportions of the northern or the southern part. Northern Vietnam is closer to the south Chinese mountain range that makes it possible for some Palaearctic elements to infiltrate into this area, while Southern Vietnam is closer to the Pacific region.

On the basis of the zoogeographical data provided by Balogh (1961, 1972), Hammer (1972), Gilyarov \& Krivolutsky (1975), Hammer \& Wallwork (1979), Karppinen \& Krivolutsky (1982), Karppinen et al. (1986, 1987), Balogh \& Balogh (1988, 1989, 2002, 2012), Aoki (1999), Yin Wenying et al. (2000), Corpuz-Raros (2005), Subias (2013) $[1,2,3,13,24]$, the results of the analysis of a zoogeographical characteristics of the oribatid fauna of $\mathrm{Vi}$ etnam is presented in the Figure 1.

$\begin{array}{ccccc}111 & 30 & 10 & 10 & 2 \\ 68.10 & 18.41 & 6.13 & 6.13 & 1.23\end{array}$

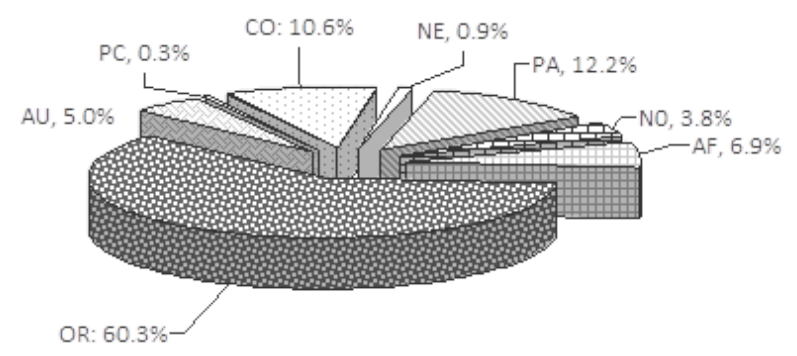

Figure 1. Zoogeographical characteristics of the oribatid mite fauna of Vietnam

Legends: (1) Oriental region: OR, (2) Palaearctic - Oriental: PA, (3) Cosmopolitan: CO, (4) Afrotropical (Ethiopical): AF, (5) Australian - Oriental: AU, (6) Neotropical Oriental: NO, (7) Nearctic - Oriental: NE, (8) Pacific Oriental: PC.

The result shows that, the oribatid mite fauna of Vietnam includes all eight zoogeographical elements. These eight zoogeographical elements can be arranged according to decreasing representation of species, as follows: (1) Oriental region (OR) occupies $60.3 \%$ of the total 320 species, with 193 species registered, (2) Palaearctic - Oriental (PA) 12.2\%, with 39 species, (3) Cosmopolitan (CO) - 10.6\%, with 34 species, (4) Afrotropical (Ethiopical) - Oriental (AF) $-6.9 \%$, with 22 species, (5) Australian - Oriental (AU) $-5.0 \%$, with 16 species, (6) Neotropical - Oriental (NO) - 3.8\%, with 12 species, (7) Nearctic - Oriental (NE) - $0.9 \%$, with 3 species, (8) Pacific - Oriental (PC) - 0.3\%, with 1 species (Figure 1).

The main zoogeographical component of the oribatid mite fauna of Vietnam are the Oriental species, representing $60.3 \%$ of the total 320 species, with 193 recorded. This oribatid mite fauna has high specialization, with 111 species (34.68\% of the total) recorded only from Vietnam (probably endemic species, i.e. conditional endemics). Besides 
that, the oribatid mite fauna of Vietnam includes also the Palaearctic - Oriental elements, with 39 species recorded, and cosmopolitan elements - 34 species, representing $12.2 \%$ and $10.6 \%$ of the total, respectively. The other categories are represented by a smaller number of species. There is now Antarctic element recorded in the oribatid mite fauna of Vietnam.

\section{CONCLUSIONS}

The oribatid mite fauna (Acari: Oribatida) of Vietnam is diversified, and has high specialization. It is diverse by the number of superfamilies, families, genera and species recorded. However, the number of genera per family, as well as the number of species and subspecies per genus, is not high. $43.75 \%$ and $37.50 \%$ of the total 64 families and subfamilies consist of one and of 2-3 genera, respectively. The only one family Oppiidae Grandjean, 1954 consists of 23 genera. The majority of the genera, $68.10 \%$ of the total, are represented by one species. The only two genera are represented by more than 10 species, namely Galumna Heyden, 1826 and Pergalumna Grandjean, 1936, with 13 and 11 species, respectively.

The main zoogeographical characteristics of the oribatid mite fauna of Vietnam are the Oriental species.

Acknowledgements: This research is funded by Vietnam National Foundation for Science and Technology Development (NAFOSTED) under grant number 106.14-2012.46. The first author thanks Prof. B. Georgiev and Assoc. Prof. Anna Ganeva for their assistance during his study visit, November-December 2015, at the Institute of Biodiversity and Ecosystem Research (IBER: BAS) Sofia, Bulgarian.

\section{References}

[1] Balogh J, P. Balogh 1992. The Oribatid Genera of the World, HNHM Press, Budapest, V.1, 263p, V.2, $375 \mathrm{p}$.

[2] Balogh J., P. Balogh 2002. Identification Keys to the Oribatid Mites of the Extra-Holarctic Regions. WellPress Publishing Limited. Budapest, V. I, 451p. and V.II, 504p.

[3] Balogh J., S. Mahunka 1967. New oribatids (Acari, Oribatei) from Vietnam.- Acta Zoologica Hungarica, 13(1-2): 39-74.

[4] Behan-Pelletier V. 1999. Oribatid mite biodiversity in agroecosystems role for bioindication.- Agriculural Ecosysustem and Environment, 74: 411-423.

[5] Đào Duy Trinh, Trịnh Thị Thu, Vu Quang Manh, 2010: Dẫn liệu về thành phần loài, phân bố và địa động vật của khu hệ ve giáp ở VQG Xuân Sơn, Phú Thọ.- Tạp chí Khoa học ĐHQG Hà Nội, 26(1): 49-56.

[6] Edwards C. A. 1991. The assessment of population of soil-inhabiting invertebrates.- Agriculural Ecosysustem and Environment, 34: 145-176.

[7] Ermilov SG, 2015, A list of oribatid mites (Acari, Oribatida) of Vietnam, Zookeys. 2015; (546): 61-85.

[8] Ermilov S. G., Anichkin A. E., 2014. Taxonomy study of oribatid mites (Acari, Oribatida) of Bu Dup
- Nui Ba National Park (Southern Vietnam).Zootaxa, 3834(1): 1-86.

[9] Ermilov S.G., Vu Q. M., 2012. Two new species of oribatid mite (Acari: Oribatida) from Phong Nha - Ke Bang National Park of Central Vietnam. International Journal of Acarology 38, 2, 160-167.

[10] Ermilov SG, Anichkin AE, Wu D., 2012. Oribatid mites from Bu Gia Map National Park (Southern Vietnam), with description of a new species of Dolicheremaeus (Tetracondylidae)(Acari: Oribatida). Genus. 23(4):591-601.

[11] Ermilov S.G., Vu Q. M., Trinh T. T. and Dao D. T., 2011. Perxylobates thanhoaensis, a new species of oribatid mite from Vietnam (Acari: Oribatida: Haplozetidae). International Journal of Acarology, 37, 2, 161-166

[12] Fernandez N., Theron P., Rollard C., Casillo E. R., 2014: Oribatid mites from deep soils of Hòn Chông limestone hills, Vietnam: the Family Lohmanniidae (Acari: Oribatida), with the descriptions of Bedoslohmannia anneae n.gen., n. sp., and Paulianaqcarus vietnamese $\mathrm{n}$. sp. Zoosystema 36(4), 771787.

[13] Ghilarov M., D. Krivolutsky 1975. Identification of Soil mites Sarcoptiformes, Nauka, Moscow, 491p. (in Russ.).

[14] Jeleva M., M. Q. Vu 1987. New Oribatids (Oribatei, Acari) from the Northern part of Vietnam. Acta Zoologica Bulgarica, 33, 10-18.

[15] Krivolutskyi et al. 1997 (Криволуцкий Д. А., Ву Куанг Мань, Фан Тхе Вьет 1997). Панцирных клещеи (Acari: Oribatei) Вьетнама. Тропическая медицина, Т. I, Тропцентр, Наука, Москва - Ханои, 152-167 (In Russ.).

[16] Mahunka S., 1987. A survey of the Oribatid (Acari) fauna of Vietnam. I., Annals. Hist.-nat. Mus. natn. Hung., 79, 259-279.

[17] Mahunka S., 1988. A survey of the Oribatid (Acari) fauna of Vietnam. II, Act. Zool. Hung., 34 (2-3), $215-$ 246.

[18] Mahunka S., 1989. A survey of the Oribatid (Acari) fauna of Vietnam. III, Folia Entomologica Hungarica, L, 47-59.

[19] Minor M. A., Ermilov, S. G. 2015. Effects of topography on soil and litter mites (Acari: Oribatida, Mesostigmata) in a tropical monsoon forest in Southern Vietnam. Experimental and Applied Acarology, 67(3), 357-372.

[20] Nguyễn Hải Tiến, Vũ Quang Mạnh, 2012: Thành phần loài ve giáp (Acari: Oribatida) ở vườn quốc gia Phong Nha - Kẻ Bàng, Quảng Bình. Tạp chí Khoa học ĐHQGHN, Khoa học Tự nhiên và Công nghệ, 28(2012), 125-134.

[21] Nguyễn Huy Trí, Lại Thu Hiền, Nguyễn Hải Tiến, Vũ Quang Mạnh, 2014: Cấu trúc quần xã xã ve giáp (Acari: Oribatida) như yếu tố chỉ thị sinh học sự biến đổi sinh cảnh ở Vườn Quốc gia Cát Bà, thành phố Hải Phòng. Tạp chí Khoa học, ĐHQG Hà Nội, 268-274. 
[22] Norton R. A., V. Behan-Pelletier 2009. Chapter 15. Suborder Oribatida. 430-564pp.. in: KRANTZ, G.W.; WALTER, D.E. (eds) A manual of acarology. Third edition. Texas Tech University Press, Lubbock Texas.

[23] Schatz H. et al. 2011. Suborder Oribatida van der Hammen, 1968. In: Zhang Z. -Q. (ed.) 2011. Animal biodiversity: an outline of higher-level classification and survey of taxonomic richness. Zootaxa, 3148: 141-148.

[24] Subias L. S. 2013. Listado sistemático, sinonímico y biogeográfico de los ácaros oribátidos (Acariformes: Oribatida) del mundo (excepto fósiles) Graellsia 60 (número extraordinario). $1-570 \mathrm{p}$. (http://www.ucm.es/info/zoo/Artropodos/ Catalogo.pdf).

[25] Udvardy M. D. F. 1975. A classification of the biogeographic provinces of the World. IUCN. Morges.

[26] Vietnam Ministry of Agriculture and Rural Development 2006. Forest area and forest land not used for forestry planning. Agricultural Publishing House, 152 p. Hanoi (In Vietnamese).

[27] Vietnam National Institute for Soils and fertilizers 2002. The basic information of main soil units of Vietnam. Thegioi Publishers. Hanoi. 1-158.

[28] Vietnam Soil Society 2000. The Soils of Vietnam. Agricultural Publishing House, Hanoi. 1-412 (In Vietnamese).

[29] Vu Quang Manh 1985 (Ву Куанг Манх). Фаунистично - екологично иследване върху орибатеите (Acari: Oribatei) в северната част на Виетнам.Дисертация Канд. Биолог. Науки, София, 1-175 (in Bulg.).
[30] Vũ Quang Mạnh, 1990. Chân khớp bé (Microarthropoda) trong quần lạc động vật đất ở Việt Nam. Tạp chí Sinh học, 12, 1, 3-10.

[31] Vu Q. M., Nguyen T. T. 2000. Microarthropod community structures (Oribatei and Collembola) in Tam Dao National Park. Journal of Biosciences. 25(4): 379-386.

[32] Vũ Quang Mạnh, 2007. Động vật chí Việt Nam, T. 21: Bộ Ve giáp Oribatida, Nxb KHKT, 1-355.

[33] Vu Q. M. 2012. Oribatid soil mite (Acari: Oribatida) of northern Vietnam: Species distribution and densities according to soil and habitat type. The Pan-Pacific Entomologist, 87(4), 209-222.

[34] Vu Quang Manh, 2013. The Oribatida (Acari: Oribatida) fauna of Vietnam. Institute of Biodiversity and Ecosystem Research (IBER: BAS), DSc. Thesis, 205p. (www.ecolab.bas.bg/main/ Members/ gpv/ $\mathrm{Vu} . . . / \mathrm{Vu}$ _Manh_Thesis_all.pdf).

[35] Vu Quang Manh, 2015. The oribatid mite fauna (Acari: Oribatida) of Vietnam - Systematics, Zoogegraphy and Formation, PENSOFT Publishers, SofiaMoscow. 1-212.

[36] Vu Q. M., Nguyen T. T. 2000. Microarthropod community structures (Oribatei and Collembola) in Tam Dao National Park. Journal of Biosciences. 25(4): 379-386.

[37] Vu Quang Manh, Ermilov S.G., Dao Duy Trinh, 2010: Two new species of Oribatid Mites (Acari: Oribatida) from Vietnam. Tạp chí Sinh học, 32(3), 1219.

[38] Vu T. L., C. Taillard 1994. Atlas of Vietnam (Cartographic material), RECLUS, Montpellier, Paris, 1$421 \mathrm{pp}$. 